J. Lake Sci. (湖泊科学), 2015, 27(6): 1124-1132

DOI 10. 18307/2015. 0618

(C) 2015 by Journal of Lake Sciences

\title{
水华生消过程中巢湖水体和沉积物理化性质变化特征”
}

\author{
习晓君 ${ }^{1}$, 李一蒇 ${ }^{2}$, 何彦芳 ${ }^{1}$, 王曙光 $^{3,4 * *}$, 王鹏腾 ${ }^{3}$ \\ (1:环境保护部环境工程评估中心, 北京 100012) \\ (2: 中国环境科学研究院环境基准与风险评估国家重点实验室, 北京 100012) \\ ( 3 : 北京化工大学环境科学与工程系, 北京 100029) \\ (4: 北京市环境污染控制与资源化工程研究中心, 北京 100029)
}

\begin{abstract}
摘 要: 湖泊水华存在复杂的生消过程, 然而目前较多研究聚焦在水华持续阶段对湖泊生态系统的影响, 却较少关注水 华生消过程对湖泊水体和沉积物理化性质的影响. 以巢湖为对象, 根据历史资料确定水华区和非水华区, 在相同位点分 别于水华形成前期、形成期、持续期和消亡期采集水体和沉积物样品, 分析水华生消过程对湖泊水体和沉积物理化指标 及营养盐的影响. 结果表明, 巢湖研究区域水华形成期为 5 月中旬至 6 月中旬, 持续期为 6 月中旬至 9 月上旬, 之后进人 水华消亡期. 水体透明度、 $\mathrm{pH}$ 值和溶解氧在水华区与非水华区大部分时间存在显著差异, 且随水华生消过程呈现不同的 变化趋势, 但水温、氧化还原电位和电导率在水华区和非水华区无显著差异, 并随水华生消过程呈现相同的变化趋势. 非 水华区水体和沉积物中各形态氮、磷浓度明显低于水华区, 且随时间变化幅度相对较小. 在水华区, 水体氮、磷浓度 (总溶 解性氮、硝态氮、氨氮、总氮、总溶解性磷、磷酸盐) 在水华形成期和水华持续前期呈下降趋势, 但在水华持续后期和水华 消亡期呈增加趋势; 沉积物氮、磷浓度 (总氮、总磷) 和总有机质含量显著高于非水华区, 三者在水华区和非水华区随水华 生消过程呈现不同的变化趋势. 研究表明, 水华生消过程对湖泊营养盐和水体及沉积物性质有不同的影响, 这对湖泊富 营养化治理和水华防治具有重要意义.
\end{abstract}

关键词: 巢湖; 水体;沉积物; 水华生消过程;理化性质

\section{Change characteristics of physico-chemical properties of water and sediment during the processes of algal blooms formation, outbreak and extinction in Lake Chaohu}

DIAO Xiaojun ${ }^{1}$, LI Yiwei ${ }^{2}$, HE Yanfang ${ }^{1}$, WANG Shuguang ${ }^{3,4}$ \& WANG Pengteng ${ }^{3}$

(1: Appraisal Center for Environment and Engineering, Ministry of Environmental Protection, Beijing 100012, P. R. China)

(2: State Key Laboratory of Environmental Criteria and Risk Assessment, Chinese Research Academy of Environmental Sciences, Beijing 100012, P. R. China)

(3: Department of Environmental Science and Engineering, Beijing University of Chemical Technology, Beijing 100029, P. R. China)

(4: Beijing City Environmental Pollution Control and Resource Reuse Engineering Research Center, Beijing 100029, P. R. China)

Abstract: Algal bloom ( $\mathrm{AB}$ ) is a complex process of algal formation, outbreak and extinction in lakes. Many previous studies
have focused on impacts of $\mathrm{AB}$ outbreak on aquatic eco-environment, but limited attention has been paid to the effects of $\mathrm{AB}$ forma-
tion, outbreak, and extinction on physico-chemical properties of water and sediment in lakes. In this study, the AB and the free
algal bloom ( FAB) regions were determined in Lake Chaohu on the basis of previous reports and monitoring data. Water and sedi-
ment samples were taken by sequential mode from May to September in 2012 to investigate effects of AB formation, outbreak and
extinction on physico-chemical properties of water and sediment as well as nitrogen and phosphorous concentrations in sediment.
Results showed that $\mathrm{AB}$ formation process occurred from May 15 to June 20 in Lake Chaohu, outbreak process lasted from June 20

* 国家自然科学基金项目 (41201528) 资助. 2014-08-29 收稿;2015-03-28 收修改稿. J晓君( 1975 ), 女,博士, 工程师; E-mail : diaoxiaojun2000@126. com.

** 通信作者; E-mail: shgwang2013@126. com. 
to September 5, and then extinction process started. In most cases, water transparency (SD), water $\mathrm{pH}$ and water dissolved oxygen (DO) showed significant differences between the $\mathrm{AB}$ and $\mathrm{FAB}$ regions and presented different change trends with sampling time respectively. However, water temperature, oxidation-reduction potential (ORP) and electrical conductivity (EC) did not show difference between the two regions. The concentrations of various forms nitrogen and phosphorus in water of the FAB region were significantly lower than those in water of the $\mathrm{AB}$ region, and fluctuated slightly with sampling time. In the $\mathrm{AB}$ region, however, the concentrations of TDN, $\mathrm{NO}_{3}{ }^{-}-\mathrm{N}, \mathrm{NH}_{4}{ }^{+}-\mathrm{N}$, TN, TDP and $\mathrm{PO}_{4}{ }^{3-}-\mathrm{P}$ in water showed downward trend during the $\mathrm{AB}$ formation process and the early stage of $\mathrm{AB}$ outbreak process, followed by upward trends during the later stage of $\mathrm{AB}$ outbreak and the $\mathrm{AB}$ extinction process. The concentrations of total nitrogen, total phosphorus and total organic matter in sediments of the $\mathrm{AB}$ region were significantly higher than those in sediment of the FAB region, and they showed different change trends with sampling time in the two regions respectively. This study indicated that $\mathrm{AB}$ formation, outbreak and extinction produced different impacts on the physico-chemical properties of water and sediment as well as the nitrogen and phosphorous concentrations in sediment. This result is important to control and treat eutrophication and algal bloom in lakes.

Keywords: Lake Chaohu; water; sediments; outbreak and extinction of algal blooms; physico-chemical properties

水华是富营养化湖泊在适宜的环境条件下发生的藻类恶性生长繁殖的一种现象, 是水体富营养化的一 种极端表现, 危害极大. 国内外学者已对水华进行了很多研究, 并在湖泊水华的危害、监测与预警、发生机 制、控制策略等方面取得了较大进展, 然而, 湖泊水华的防治并没有达到预期效果, 湖泊专家也指出水华形 成机制仍有很多问题有待探讨 ${ }^{[1]}$.

水华是湖泊的偶发性、阶段性事件, 虽然会因湖泊状况、气候条件等不同而在频次和强度上有所差异, 但每次水华都会历经形成、持续和消亡过程 ${ }^{[2]}$. 在水华形成阶段, 养分、空间、光照充足, 水质相对较好, 藻体 光合作用大于呼吸作用, 以快速生长为主, 死亡很少, 对湖泊生态环境的负面影响较小, 由于藻类释放 $\mathrm{O}_{2}$ 甚 至对水体溶解氧有促进作用 ${ }^{[3]}$. 在水华持续阶段, 藻类数量快速持续增加, 大面积覆盖水面, 不仅降低大气 复氧过程 ${ }^{[4]}$, 而且减少射人水体的光线, 导致水温、浮游植物光合作用、水体微生物等发生变化, 特别是非表 层藻类会因蔽光而死亡 ${ }^{[5]}$, 从而使水质越来越差. 在水华消亡阶段, 死亡的藻体分解消耗水体中大量的溶解 氧, 释放大量溶解性有机质 ${ }^{[6]}$, 微生物对有机质的降解作用增强, 释放出 $\mathrm{CO}_{2}$ 和有机酸而使水体和沉积物 $\mathrm{pH}$ 值下降. 所以, 在水华生消不同阶段, 其对湖泊环境产生的影响可能是有差异的, 然而, 目前大量研究聚焦在 水华持续阶段, 对水华生消过程的研究还比较少, 如陈红萍等 ${ }^{[3]}$ 通过室内模拟实验研究水华生消过程中多 个水质参数的变化, 发现 $\mathrm{pH}$ 值、溶解氧、叶绿素 $\mathrm{a}$ 浓度等呈现典型的先升高后下降的变化规律; 徐宁等 ${ }^{[7]}$ 研 究水华生消过程与环境因子的关系, 发现水温和光照对水华生消影响较大. 陈建良等 ${ }^{[8]}$ 研究洱海蓝藻水华 生消过程中浮游植物生物量的变化, 发现从 5 月份开始, 浮游植物生物量开始增加, 在 9 月份有稍许降低, 10 月份达到峰值, 11 月份开始下降, 浮游植物丰度和叶绿素 $\mathrm{a}$ 浓度的变化趋势基本一致. 对水华生消过程研究 的不足,将妨碍对水华影响的评价和防治水华措施的制定.

巢湖是我国污染最重的三大淡水湖泊之一, 近年来每年都会发生规模或大或小的水华现象, 由于巢湖 承担着饮用水和工农业用水供给的功能, 所以水华问题深受关注. 目前, 对巢湖富营养化及其危害的研究较 多, 但对其水华生消过程的研究还不够, 刀晓君等 ${ }^{[9]}$ 研究巢湖水华生消过程对沉积物微生物群落结构的影 响, 叶琳琳等 ${ }^{[10]}$ 研究巢湖水华期间水体溶解性碳水化合物的变化, 王书航等 ${ }^{[11]}$ 研究巢湖水环境因子时空变 化对水华发生的影响. 本研究以浅水湖泊巢湖为对象,根据历史资料确定水华区和非水华区,于 2012 年 5 月 水华发生前开始在两个区域连续采集沉积物和水样, 直至水华消亡后的 9 月份结束, 分析水华生消期间水 体和沉积物理化性质的变化, 以期为全面分析和评估水华对湖泊生态系统的影响、水华的治理控制措施等 提供参考.

\section{1 材料与方法}

\section{1 样品采集}

依据巢湖历史资料确定采样时间和地点, 采样地点要分布水华区 (处理) 和非水华区 (对照). 样品采集 工作共进行 8 次,时间分别为:5 月 15 日(水华前期)、6 月 20 日(水华形成期）、7 月 10 日、7 月 20 日、8 月 1 
日、8月 22 日、9 月 5 日 (水华持续期)、9 月 19 日(水华消亡期). 在水华区和非水华区均设置 5 个采样点, 利 用 GPS 全球卫星定位系统进行采样点的定位, 但每个区域最终有 3 个采样点符合实验要求, 即持续水华或 持续非水华. 采样点位分布见图 $1,1^{\#}$ 采样点靠近合肥市的水湾区; $2^{\#}$ 采样点位于南淝河人湖区; $3^{\#}$ 采样点位 于西半湖湖心区; $4^{\#}$ 采样点位于东西湖分界区 (姥山) $; 5^{\#}$ 采样点位于东半湖湖心区; $6^{\#}$ 采样点位于裕溪河人

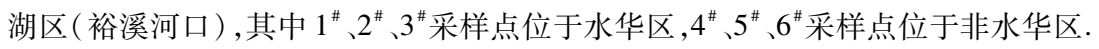

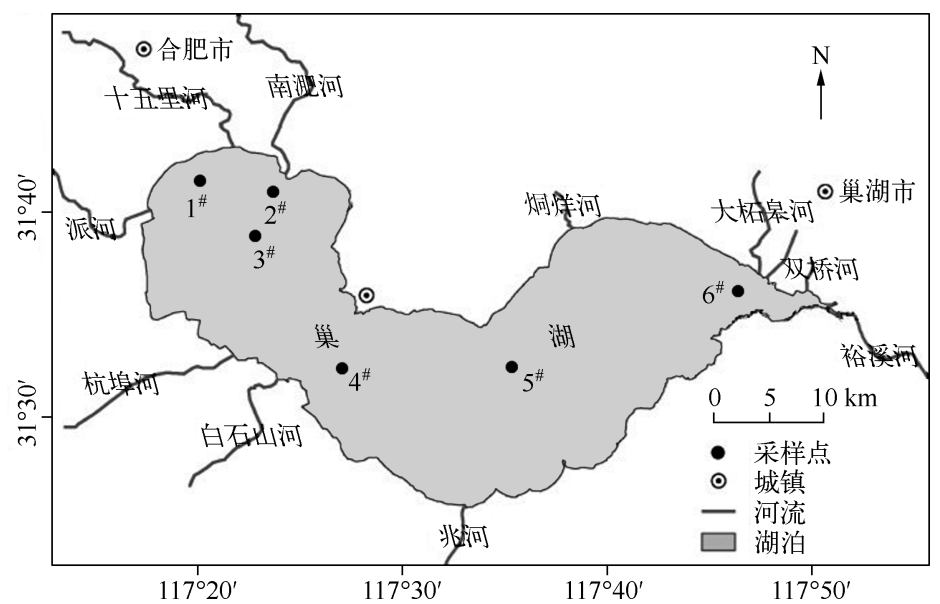

图 1 巢湖水华区和非水华区采样点位置

Fig. 1 Sampling sites in the algal bloom and free algal bloom regions of Lake Chaohu

利用彼得森采泥器采集表层 $10 \mathrm{~cm}$ 沉积物样品, 以每个样点为中心采集 3 个平行样, 现场混为 1 个样 品, 这样每个采样点只有 1 个待测样品, 本研究中 6 个采样点共 6 个样品, 水华区和非水华区各 3 个. 沉积物 样品立即装人密封袋内, 运回实验室后冷冻干燥, 研磨后过篮 (100 目), 用于沉积物理化性质的测定. 同时 利用不锈钢采水器采集水面下 $0.5 \mathrm{~m}$ 处的水样, 每个点位采集 3 个平行样, 现场混匀后收集 $1 \mathrm{~L}$, 放人 $4^{\circ} \mathrm{C}$ 保 温箱中保存, 并在 $48 \mathrm{~h}$ 内测定叶绿素 $\mathrm{a}\left(\mathrm{Chl}\right.$. a) 、总溶解性氮 $(\mathrm{TDN})$ 、总溶解性磷 $(\mathrm{TDP}) 、$ 正磷酸盐 $\left(\mathrm{PO}_{4}^{3-}-\mathrm{P}\right)$ 、硝态 氮 $\left(\mathrm{NO}_{3}^{-}-\mathrm{N}\right)$ 、铵态氮 $\left(\mathrm{NH}_{4}^{+}-\mathrm{N}\right)$ 浓度. 现场测定水温、溶解氧 $(\mathrm{DO})$ 浓度、 $\mathrm{pH}$ 值、电导率 $(\mathrm{Cond})$ 、氧化还原电位 $(\mathrm{ORP})$ 、透明度 $(\mathrm{SD})$ 等水体理化指标.

\section{2 分析方法}

水体中 $\mathrm{TDN} 、 \mathrm{TDP} 、 \mathrm{PO}_{4}^{3-}-\mathrm{P} 、 \mathrm{NO}_{3}^{-}-\mathrm{N} 、 \mathrm{NH}_{4}^{+}-\mathrm{N}$ 浓度的测定方法参考文献 [ 12]. Chl. a 浓度采用丙酮 $24 \mathrm{~h}$ 提 取法测定. 在现场利用便携式 YSI Pro Plus 水质分析仪 (美国维塞) 测定水温、DO、pH 值、Cond、ORP 等水体 理化指标, 用塞氏盘测定 SD. 沉积物中的 TP 浓度采用磷钼蓝比色法测定; 沉积物中的 TN 浓度采用碱性过 硫酸钾氧化紫外分光光度法测定; 沉积物中的 TOC 浓度采用 Multi N/C 2100 TOC/TN 分析仪(德国耶拿公 司) 和 HT1300 模块测定.

\section{3 统计分析}

通过 SPSS 13.0 软件采用 Duncan 分析方法进行差异显著性检验 $(\alpha=0.05)$.

\section{2 结果与分析}

\section{1 水华生消过程的判断}

Chl. a 浓度通常作为判断水华是否发生的依据, 但目前对 Chl. a 浓度的水华阈值还存在分歧, 如 Nurnberg ${ }^{[13]}$ 认为水体 Chl. a 浓度超过 $25 \mu \mathrm{g} / \mathrm{L}$ 即发生轻度水华, 而刘聚涛等 ${ }^{[14]}$ 结合历史资料建议把 Chl. a 浓度 $30 \mu \mathrm{g} / \mathrm{L}$ 作为水华國值. 本研究以 $30 \mu \mathrm{g} / \mathrm{L}$ 作为评判水华是否形成的标准.

在整个研究中非水华区水体 Chl. a 浓度变化不大, 所有水样的 Chl. a 浓度都低于 $20 \mu \mathrm{g} / \mathrm{L}$ (图 2), 表明 选定的非水华区一直没有典型水华发生, 采样点设置符合实验要求. 而水华区 Chl. a 浓度普遍高于非水华 
区, 且均显著高于 $30 \mu \mathrm{g} / \mathrm{L}$, 表明水华区有典 型水华持续发生, 采样点设置也符合实验要 求. 水华区 (西湖区) 的 Chl. a 浓度明显高于 非水华区 (东湖区), 这与之前的许多研究结 果一致,如缪灿等 ${ }^{[15]}$ 于 2007 年 6-11 月对巢 湖全湖的 23 个位点进行调查, 发现西湖区 Chl. a 浓度明显高于东湖区. 水华区 Chl. a 浓 度随时间波动较大, 可能与以下因素有关: (1) 天气原因, 如刮风、降雨导致藻类被分散 或稀释, 浓度下降. 7 月 10 日和 8 月 1 日 Chl.a 浓度较低, 正是因为前者遭遇了大风与降雨, 后者遭遇了双台风“苏拉” 和 “达维”, 缪灿 等 ${ }^{[15]}$ 在其研究中也发现 7 月较大的降雨量降 低了 Chl. a 浓度; (2) 水华本身的生消过程, 藻类生长周期较短, 一般为 $1 \sim 3$ 周左右, 所 以看似持续的水华其实是多个短期水华生消 过程的叠加. 总体来看, 水华区水体的 Chl. a

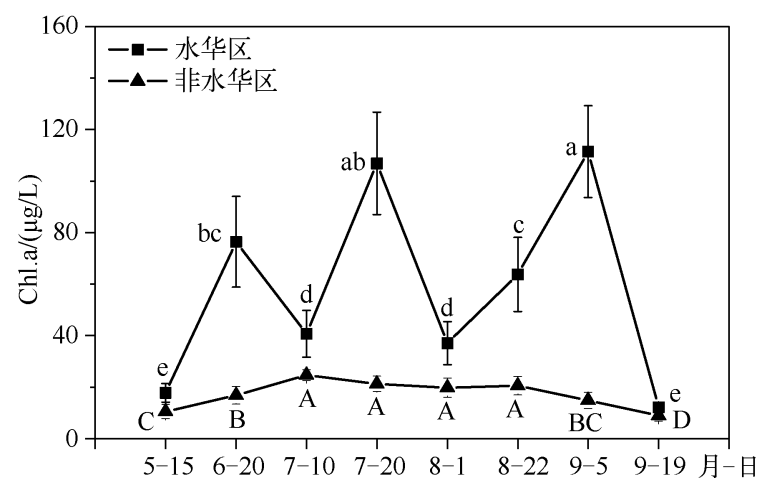

图 2 巢湖水华区和非水华区水体 Chl. a 浓度随时间的 变化(不同小写字母表示水华区水体 Chl. a 浓度在 $\alpha=$ 0.05 水平上差异显著, 不同大写字母表示非水华区水 体 Chl. a 浓度在 $\alpha=0.05$ 水平上差异显著）

Fig. 2 Changes in chlorophyll-a concentration on water in the algal bloom and free algal bloom regions of Lake Chaohu 浓度从 5 月 15 日低于 $30 \mu \mathrm{g} / \mathrm{L}$ 到 6 月 20 日 显著高于 $30 \mu \mathrm{g} / \mathrm{L}$, 呈现明显增加趋势, 表明 5 月 15 日前水体水华还没有开始形成, 5 月 15 日至 6 月 20 日水 华处于形成期, 6 月 20 日至 9 月 5 日, Chl. a 浓度始终处于较高水平, 水华处于持续期, 而 9 月 5 日之后水体 Chl. a 浓度急剧下降到 $30 \mu \mathrm{g} / \mathrm{L}$ 以下, 表明水华处于消亡期. 该变化过程与钟立香 ${ }^{[16]}$ 对巢湖 1 年多的观察结果 类似, 她发现巢湖水体中 Chl. a 浓度从 5 月开始升高, 在 8 月达到最高值; 孔明等 ${ }^{[17]}$ 从全巢湖角度计算, 发 现 7 月水体 Chl. a 浓度比 4 月增加近 2 倍. 本研究中, 5 月 15 日前藻类没有明显生长, 是因为温度没有达到 藻类恢复生长的条件, 虽然不同蓝藻种类生长需要的最低温度不同, 但低温不利于藻类的生长. Schöne 等 ${ }^{[18]}$ 发现春季升温可激活沉积物表面的藻体并促进藻体从沉积物到水体迁移.

\section{2 水华生消过程对水体理化性质的影响}

2.2.1 水华生消过程中水体理化指标的变化 水华区和非水华区水体理化指标随水华生消过程变化(图 3 ) 表明,多数情况下水华区与非水华区水体 SD、pH 值和 DO 有显著差异,而水温、ORP 和 Cond 没有显著差异.

浅水湖泊水体的 SD 受季节、温度、湖水量、风浪等影响. 从水华生消过程看,非水华区水体 SD 在 7 月 10 日前随时间呈下降趋势, 之后呈持续增加趋势 (图 3a). 前期 SD 下降与水温升高、水生生物活动增加、沉水 植物生长等有关, 后期 SD 升高与水生植物净化能力增强、降雨量增大有关. 水华区水体 SD 在 7 月 20 日前 随时间直线下降, 主要与水温升高导致的藻类和其他水生动植物生物量增加有关, 8 月份 SD 较高可能与雨 水较多有关. 9 月 19 日 SD 较高与水华处于消亡期、大量藻类快速死亡分解有关 (图 3a). 总体来看, 水华区 水体 SD 明显低于非水华区. 这与邹清等 ${ }^{[19]}$ 对巢湖东、中、西湖区进行长达 1 年的观察结果一致, 他们发现水 华区 (西湖区) 的 SD 明显低于非水华区 (东湖区).

水华区和非水华区水体 $\mathrm{pH}$ 值多数情况下存在显著差异 (图 3b). 非水华区水体 $\mathrm{pH}$ 值呈先升高后稳定 的变化趋势, 这可能是因为随着水体温度升高水生植物光合作用消耗水体中的 $\mathrm{CO}_{2}$ 并释放 $\mathrm{O}_{2}$, 而水体中 $\mathrm{CO}_{2}$ 浓度变化会影响水体 $\mathrm{pH}$ 值 ${ }^{[20]}$, 从而导致 7 月 20 日前水体 $\mathrm{pH}$ 值呈升高趋势; 7 月 20 日后水体 $\mathrm{pH}$ 值达 到一个新的平衡, 尽管 9 月水生植物死亡会分解释放出部分有机酸, 但由于释放量有限, 所以对水体 $\mathrm{pH}$ 值 仅产生轻微影响. 孔明等 ${ }^{[17]}$ 对全巢湖的研究表明夏季水体 $\mathrm{pH}$ 值略高于春季. 水华区水体 $\mathrm{pH}$ 值呈先升高后 下降的变化趋势 (7 月 10 日除外), 前期 $\mathrm{pH}$ 值升高的原因与非水华区一致, 不过藻类的存在导致水华区水 体 $\mathrm{pH}$ 值明显高于非水华区; 后期 $\mathrm{pH}$ 值下降可能是由于随着水华接近消亡, 死亡藻类增加, 腐烂分解时释放 出大量 $\mathrm{CO}_{2}$ 和有机酸所致, 这也导致水华区水体 $\mathrm{pH}$ 值显著低于非水华区. 7 月 10 日水华区水体 $\mathrm{pH}$ 值骤然 下降, 并低于非水华区, 这与采样当天风浪较大, 导致水一沉积物界面物质交换作用加强有关, 而水华区沉积 
-匹一水华区 - - - 非水华区
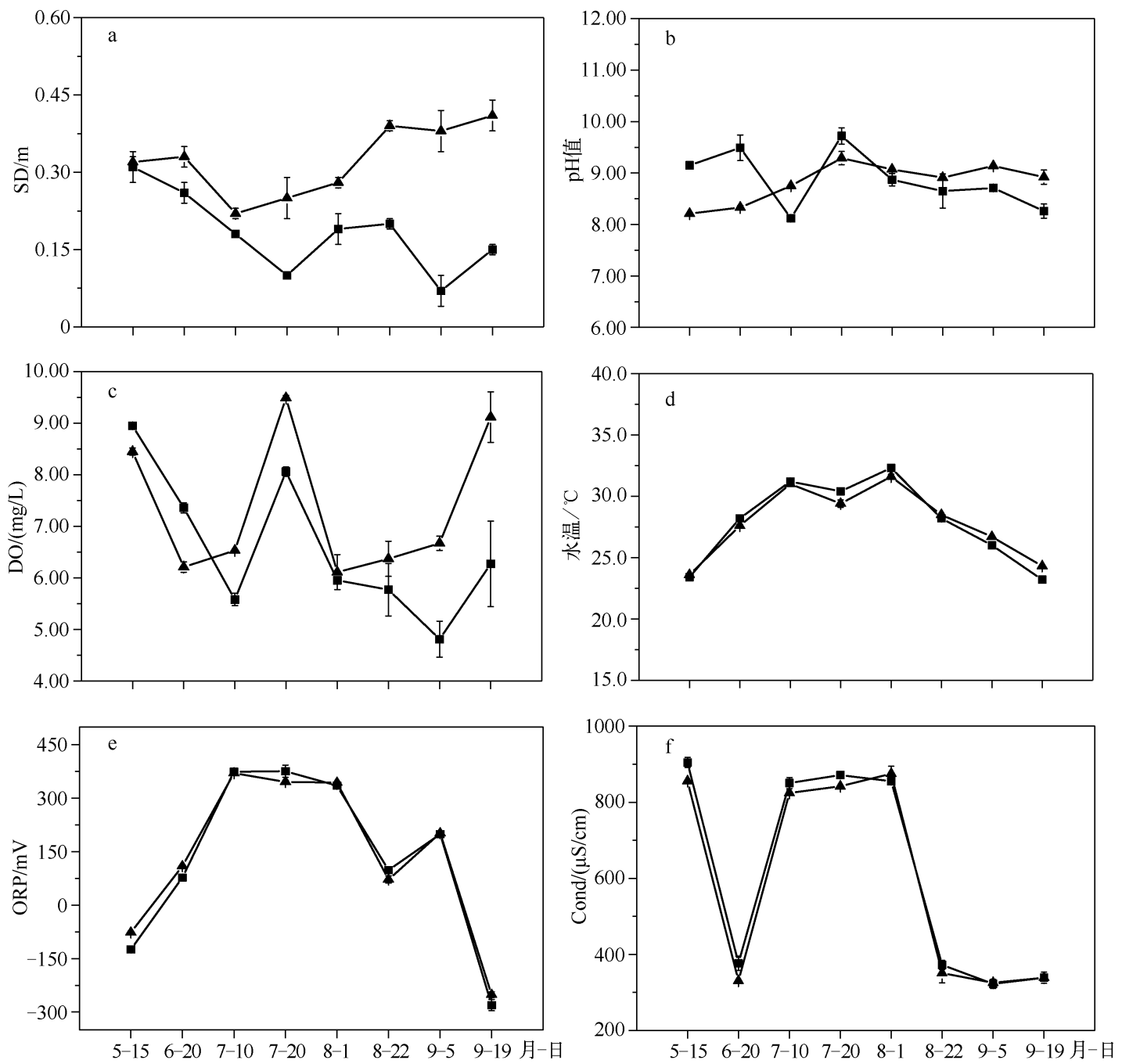

图 3 巢湖水华区和非水华区水体理化性质随时间的变化

Fig. 3 Changes in the physico-chemical properties of water in the algal bloom and free algal bloom regions of Lake Chaohu with sampling time

物中有机质含量高, 部分有机物降解过程中会产生大量的有机酸 ${ }^{[21]}$, 从而导致当天水华区 $\mathrm{pH}$ 值明显下降. 据报道, 大型浅水湖泊比小型湖泊更易受风浪影响, 可使 $0.4 \sim 3.8 \mathrm{~mm}$ 的沉积物进人水体 ${ }^{[22]}$. 本研究中 2 个 采样区 $\mathrm{pH}$ 值的变化趋势 (7 月 10 日除外) 与邹清等 ${ }^{[19]}$ 对巢湖东、中、西湖区进行 1 年观察的结果一致, 即 $\mathrm{pH}$ 值从春季到 8 月呈增加趋势, 之后呈下降趋势.

DO 浓度是影响水生生物生存和水体质量的关键因子之一. 除 5 月 15 日和 6 月 20 日水华区 DO 浓度高 于非水华区外,其他 6 次调查结果均为水华区低于非水华区 (图 3c). 前 2 次水华区 DO 浓度较高可能是因 为此阶段藻体以快速生长为主, 死亡的很少, 光合作用消耗水体中的 $\mathrm{CO}_{2}$, 产生 $\mathrm{O}_{2}$, 导致水体 $\mathrm{DO}$ 浓度明显 较非水华区高. 6 月 20 日以后进人水华持续期, 藻体死亡增加, 分解过程消耗大量水体 DO, 同时大量藻体覆 盖在水面, 阻碍氧分子由空气向水体的扩散 ${ }^{[6]}$, 从而使水华区 DO 浓度明显低于非水华区. 从 DO 浓度随时 间的变化看, 水华区和非水华区 DO 浓度变化都很大, 这是因为 DO 浓度除受水华影响外还受其他因素的影 响, 如水温、风浪、人为因素等. 水体 DO 浓度在 7 月 10 日前呈持续下降趋势可能与温度升高有关, 而 7 月 22 
日 DO 浓度升高也与当天温度较低相对应. 8 月 1 日以后非水华区 DO 浓度由于水温逐渐下降而升高, 但水 华区 DO 浓度由于藻体的降解却仍处于低值, 直到 9 月 19 日水华消退 DO 浓度才得以升高. 总体来看, 在非 水华区 DO 浓度主要受温度影响, 而在水华区藻类的生消对 DO 浓度则产生更大的影响. 在整个调查期间, 水华区与非水华区的水温、ORP 和 Cond 基本相同, 随时间变化趋势也相同 (图 $3 \mathrm{~d} 、 \mathrm{e} 、 \mathrm{f}$ ), 说明水华的暴发并 没有对其产生较大的影响,也可能是其它因素的影响掩盖了水华的影响.

2.2 .2 水华生消过程中水体不同形态氮浓度的变化 氮是藻类生长必需的营养元素, 水体中较高浓度的氮 是水华发生的必要条件之一. 除 8 月 1 日和 8 月 22 日, 非水华区水体 $\mathrm{TDN} 、 \mathrm{NO}_{3}^{-}-\mathrm{N} 、 \mathrm{NH}_{4}^{+}-\mathrm{N}$ 和 $\mathrm{TN}$ 浓度远低 于水华区 (图 4), 这与叶琳琳等 ${ }^{[10]}$ 的调查结果一致, 主要是由于巢湖西区邻近合肥市, 南淝河有大量生活污 水和工业废水排人, 此外, 这些区域多年暴发水华, 沉积物氮含量高也是原因之一. 从水华生消过程来看, 非 水华区水体 $\mathrm{TDN} 、 \mathrm{NO}_{3}^{-}-\mathrm{N} 、 \mathrm{NH}_{4}^{+}-\mathrm{N}$ 和 $\mathrm{TN}$ 浓度随时间有轻微下降趋势, 可能主要由温度升高导致的生物转化 以及水生植物代谢所致 ${ }^{[23]}$. 而水华区 4 种形态氮浓度总体上呈先降低后上升的变化趋势, 即在水华的形成 和持续期前期呈下降趋势, 但在水华持续期后期和消亡期则呈增加趋势. 前期水体 4 种氮浓度下降可能主 要与藻类的直接吸收及沉降有关, 徐宁等 ${ }^{[7]}$ 发现藻类可选择性吸收 $\mathrm{NO}_{3}^{-}-\mathrm{N} 、 \mathrm{NO}_{2}^{-}-\mathrm{N}$ 和 $\mathrm{NH}_{4}^{+}-\mathrm{N}$; 但在后期 4 种氮浓度升高则可能与藻类死亡分解氮素释放、厌氧环境下沉积物释放增加等有关 ${ }^{[24]}$, 张彩云等 ${ }^{[25]}$ 通过对 太湖水华的室内模拟实验也发现类似现象. 此外, 前期 $\mathrm{NO}_{3}^{-}-\mathrm{N}$ 浓度的下降还与水体 DO 浓度下降导致的反 硝化作用增强有关, 而后期 $\mathrm{NO}_{3}^{-}-\mathrm{N}$ 浓度升高也与水体 $\mathrm{DO}$ 浓度增加、硝化作用增强有关. 不过由于氮浓度变 化是沉积物、水体和藻体三者氮转化的综合影响, 所以 $\mathrm{NH}_{4}^{+}-\mathrm{N}$ 和 $\mathrm{NO}_{3}^{-}-\mathrm{N}$ 浓度变化并未与硝化及反硝化作 用的强弱变化对应起来. 7 月 10 日水华区水体中 $\mathrm{TDN} 、 \mathrm{NO}_{3}^{-}-\mathrm{N}$ 和 $\mathrm{TN}$ 浓度明显增加, 可能与当天风浪导致底 泥释放 $\mathrm{NO}_{3}^{-}-\mathrm{N}$ 有关. 8 月 1 日和 8 月 22 日水华区水体 $\mathrm{TDN} 、 \mathrm{NO}_{3}^{-}-\mathrm{N} 、 \mathrm{NH}_{4}^{+}-\mathrm{N}$ 和 $\mathrm{TN}$ 浓度明显较低, 与 8 月降 雨量较大有关, 2012 年 7、8 月的平均降雨量分别为 $117.4 、 178.2 \mathrm{~mm}$.
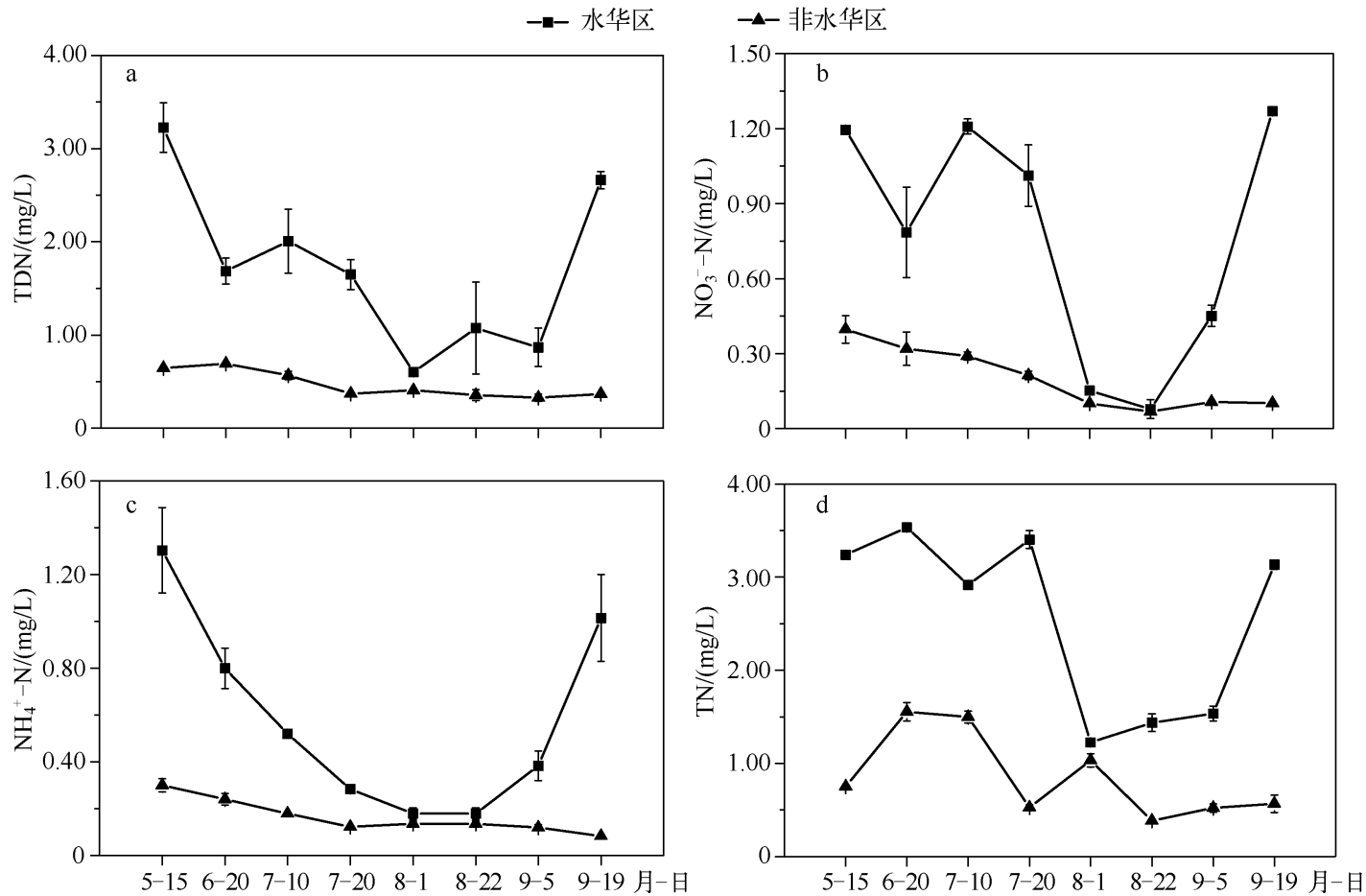

图 4 巢湖水华区和非水华区水体各形态氮浓度随时间的变化

Fig. 4 Changes in the nitrogen concentrations in water of the algal bloom and free algal bloom regions of Lake Chaohu with sampling time 
2.2 .3 水华生消过程中水体不同形态磷浓度的变化 水体中磷是藻类生长必需的营养元素, 通常是湖泊藻 类生长繁殖的主要限制因素之一.

非水华区水体 $\mathrm{TDP} 、 \mathrm{PO}_{4}^{3-}-\mathrm{P}$ 和 TP 浓度明显比水华区低 (图 5), 这与叶琳琳等 ${ }^{[13]}$ 的调查结果一致, 原因 与水华区氮素浓度较高类似. 从水华生消过程来看, 非水华区水体 $\mathrm{TDP}$ 和 $\mathrm{PO}_{4}^{3-}-\mathrm{P}$ 浓度随时间呈小幅下降趋 势, 这可能主要与水生植物生长吸收有关. 水华区水体 $\mathrm{TDP}$ 和 $\mathrm{PO}_{4}^{3-}-\mathrm{P}$ 浓度随时间呈现先降低后上升的趋 势, 即在水华形成期和持续期前期呈持续下降趋势, 在水华持续期后期和消亡期呈增加趋势. 因为 $\mathrm{PO}_{4}^{3-}-\mathrm{P}$ 是藻类生长繁殖能够直接利用的磷形态, 在水华形成及持续阶段会被大量消耗, 导致水华区 $\mathrm{PO}_{4}^{3-}-\mathrm{P}$ 浓度明 显下降, 而在水华持续期后期和消亡期, 由于藻类腐烂分解会释放一定量的 $\mathrm{PO}_{4}^{3-}-\mathrm{P}^{[26]}$, 再加上沉积物的释 磷作用, 水体 $\mathrm{PO}_{4}^{3-}-\mathrm{P}$ 和 TDP 浓度会明显上升. 然而水华区和非水华区 $\mathrm{TP}$ 浓度随水华生消的变化趋势却与 $\mathrm{TDP}$ 和 $\mathrm{PO}_{4}^{3-}-\mathrm{P}$ 浓度完全不同 (图 5c), 这是由于 $\mathrm{TP}$ 包括多种形态的磷, 从 3 种形态磷浓度的大小也可以发 现, $\mathrm{PO}_{4}^{3-}-\mathrm{P}$ 和 TDP 浓度只占 TP 浓度较小的比例, 此外 TDP 和 $\mathrm{PO}_{4}^{3-}-\mathrm{P}$ 比其他形态的磷更易发生转化, 所以 三者变化趋势不同. 这也意味着, 巢湖水体中还有其他形态浓度较高的磷, 今后应予以重视. 7 月 10 日 TP 浓 度较高可能与当天特殊的天气条件有关.

\section{3 水华生消过程中沉积物理化性质的变化}

水华区沉积物 TN 含量明显高于非水华区 (图 6a), 这与流人该区域的水中氮浓度较高以及该区域近年 频繁发生水华, 藻类死亡后一部分有机体沉降到沉积物有关. 该结果与之前的较多报道一致, 如王书航等 ${ }^{\left[{ }^{[26]}\right.}$ 对 巢湖沉积物氮素形态特征进行调查, 发现 TN 含量呈西湖区高、东湖区低的特点. 非水华区沉积物 TN 含量呈现 出先降低后小幅波动的变化趋势, 前期下降可能与温度升高、沉积物微生物活性增强、氮代谢加速有关. 水华 区沉积物 TN 含量呈现较大的波动, 这与水华导致的藻体碎屑沉降、水体 $\mathrm{pH}$ 值变化、风浪等有很大关系, 如孔 明等 ${ }^{[17]}$ 发现巢湖西湖区忠庙镇附近是蓝藻聚集区, 藻体沉降导致 7 月沉积物的 TN 含量明显高于 4 月; 同时也 发现, 从全巢湖来看, 水华前后沉积物 TN 含量并未发生明显变化, 这可能与全湖区数据平均掩盖了水华对 TN 含量的影响有关. 此外, 水体 $\mathrm{pH}$ 值和 DO 浓度的变化会影响硝化和反硝化微生物, 也会影响氮的转化及浓度.

水华区沉积物 TP 含量显著高于非水华区 (图 6b), 主要是因为该区域长期发生水华, 藻类碎屑大量沉 降, 此外, 该区域靠近合肥市, 接纳了大量的污水和地表水, 再加上西湖区四周高、中间低的地形, 从而使得沉 积物 TP 含量较高. 虽然水华区和非水华区沉积物 TP 含量都随时间呈增加趋势, 但水华区 TP 含量增加的趋势 更明显且波动较大, 这可能与水华区沉积物 TP 含量较高, 易受环境条件影响有关, 如风浪、温度升高等.7月 10 日和 8 月 1 日水华区沉积物 TP 含量相对较低, 是受当天风浪导致沉积物再悬浮, 有一部分颗粒态 P 释放到水 体中, 另外, 由于风浪加剧上覆水和沉积物间隙水之间的交换, 导致沉积物 $\mathrm{pH}$ 值升高, 而沉积物 $\mathrm{pH}$ 值的升高 有利于 P 的释放, 因此也会导致沉积物中 TP 含量的降低. 9 月 19 日水华区沉积物 TP 浓度出现明显下降, 这是 因为水华区沉积物中 TP 主要来自湖泊自生性磷沉降,而自生性磷会被微生物优先利用 ${ }^{[27]}$, 在微生物的作用下 可能很快矿化释放到水体中, 这也与水体中 TDP 浓度在 9 月 19 日出现明显升高相一致(数据未列出).

非水华区和水华区沉积物 TOC 含量差异显著, 水华区沉积物中 TOC 含量普遍高于非水华区 (图 6c), 这 与备逢宇等 ${ }^{[28]}$ 发现巢湖从西湖区 (水华区) 到东湖区 (非水华区) 沉积物 TOC 含量逐渐下降的结果一致. 主 要原因是水华区藻类等初级生产者较多, 产生的有机质沉降到沉积物中导致 TOC 含量较高, 此外, 来自合肥 市的工业与生活废水携带大量有机物流人西湖区 (水华区) 也不可忽视. 周志华等 ${ }^{[29]}$ 对近百年来巢湖沉积物 有机质的来源分析发现, 水生藻类是主要来源, 其次是城市污水和农业面源污染. 非水华区沉积物 TOC 浓度随 水华生消过程总体呈现下降趋势, 可能与夏季沉积物微生物活性及生物量较高、有机质的矿化速率较快有关. 水华区沉积物 TOC 含量在水华形成期增加,在水华持续期维持在较高水平,在水华消亡期下降. 7 月 10 日和 8 月 1 日水华区沉积物 TOC 含量显著下降, 可能与当天风浪较大导致大量沉积物悬浮到水体中有关.

\section{3 结论}

1) 5 月 15 日前水体 Chl. a 浓度低于 $20 \mu \mathrm{g} / \mathrm{L}$, 未达水华标准; 5 月 15 日至 6 月 20 日 Chl. a 浓度快速增 加至 $80 \mu \mathrm{g} / \mathrm{L}$, 为水华形成期; 6 月 20 日至 9 月 5 日 Chl. a 浓度持续在高位波动, 为水华持续期, 9 月 5 日后 Chl. a 浓度快速下降至 $30 \mu \mathrm{g} / \mathrm{L}$ 以下, 为水华消亡期. 

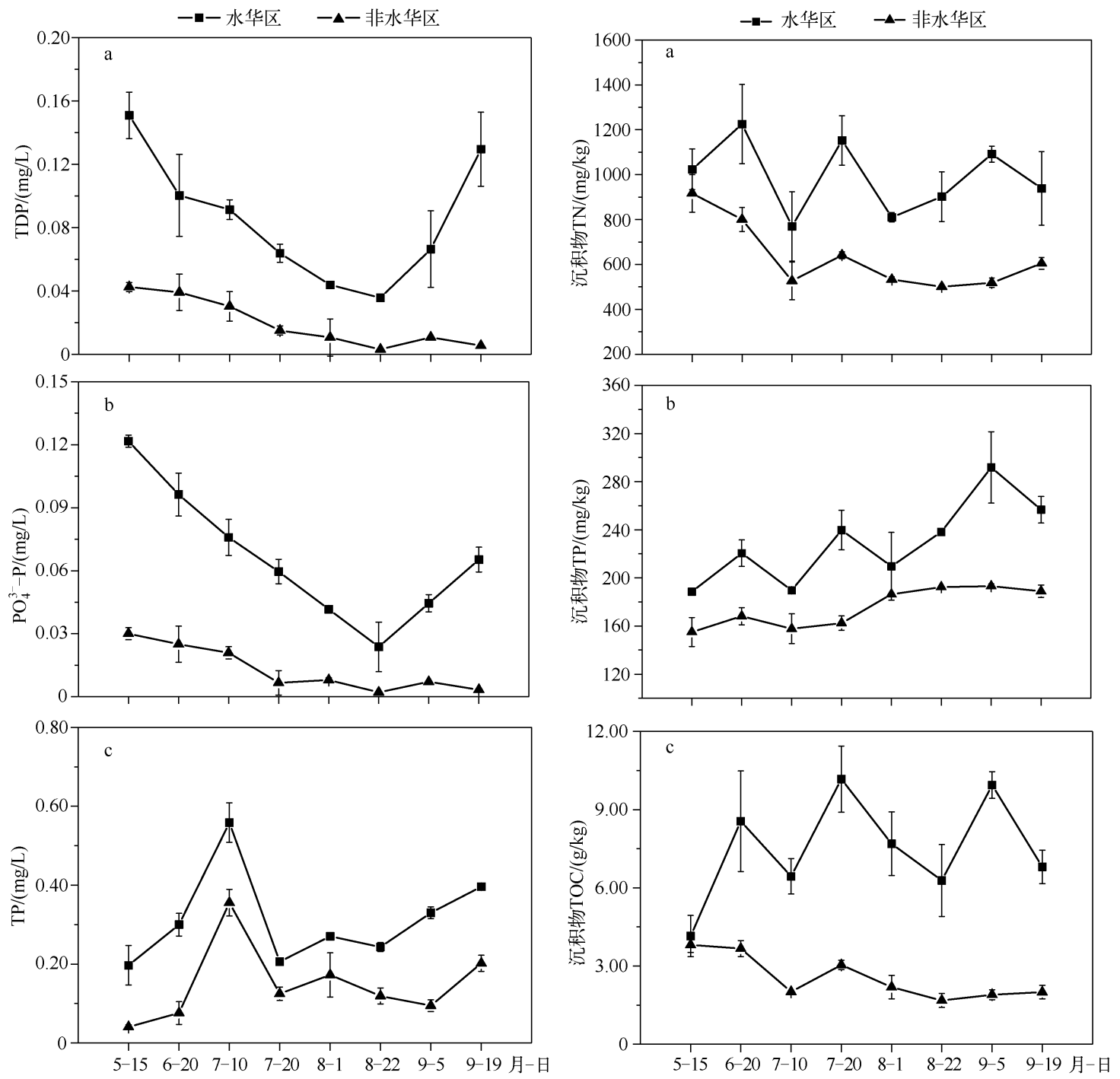

图 5 巢湖水华区和非水华区水体

各形态磷浓度随时间的变化

Fig. 5 Changes in the phosphorus concentrations in water of the algal bloom and free algal bloom regions of Lake Chaohu with sampling time

图 6 巢湖水华区和非水华区沉积物 TN、 TP 和 TOC 含量随时间的变化

Fig. 6 Changes in TN, TP and TOC contents in the sediment of the algal bloom and free algal bloom regions of Lake Chaohu with sampling time

2) 与非水华区相比, 水华生消过程对水体理化性质和氮磷浓度产生了不同影响, 主要表现在水体 SD 显著降低, 水华前期 $\mathrm{pH}$ 值和 DO 浓度升高以及水华后期两者的下降. 水华区水体各种形态氮、磷浓度明显 高于非水华区, 且随水华生消过程总体呈现先降低 (水华形成期和持续前期)后上升 (水华持续后期和消亡 期) 的趋势,但在非水华区氮、磷浓度随时间变化不显著.

\section{4 参考文献}

[1 ] 孔繁翔,宋立荣. 蓝藻水华形成过程及其环境特征研究. 北京:科学出版社,2011.

[ 2 ] Davis TW, Berry DL, Boyer GL et al. The effects of temperature and nutrients on the growth and dynamics of toxic and non- 
toxic strains of Microcystis during cyanobacteria blooms. Harmful Algae, 2009, 8(5) :715-725.

[3] 陈红萍, 王 涛, 赵 策等. 室内太湖水华形成与消亡、 $\mathrm{CO}_{2}$ 反应速率及其相关参数变化趋势的研究. 工业微生物, $2013, \mathbf{4 3}(3): 7-11$.

[4] 贾晓会, 施定基, 史绵红等. 巢湖蓝藻水华形成原因探索及 “优势种光合假说”. 生态学报, 2011,31 ( 11): 2968-2977.

[ 5 ] 朱梦圆, 朱广伟,王永平. 太湖蓝藻水华衰亡对沉积物氮、磷释放的影响. 环境科学, 2011,32(2):409-416.

[ 6 ] Ye LL, Shi X, Wu XD et al. Dynamics of dissolved organic carbon after a cyanobacterial bloom in hypereutrophic Lake Taihu (China). Limnologica, 2011, 41(4) :382-388.

[ 7 ] 徐 宁, 陈菊芳, 王朝晖等. 广东大亚湾藻类水华的动力学分析 I 藻类水华的生消过程及其与环境因子的关系. 海 洋环境科学, $2001, \mathbf{2 0}(2): 1-6,12$.

[8] 陈建良, 胡明明, 周怀东等. 洱海蓝藻水华暴发期浮游植物群落变化及影响因素. 水生生物学报, 2015,39 (1): 24-28.

[9] ᄀ晓君, 李一蒇, 王曙光. 水华生消过程对巢湖沉积物微生物群落结构的影响. 环境科学, 2015,36(1):107-113.

[10] 叶琳琳, 史小丽, 张 民等. 巢湖夏季水华期间水体中溶解性碳水化合物的研究. 中国环境科学, 2012,32(2): $318-323$.

[11] 王书航,姜 霞,金相灿. 巢湖水环境因子的时空变化及对水华发生的影响. 湖泊科学, 2011,23(6):873-880. DOI 10. $18307 / 2011.0608$.

[12] 高延耀,顾国维, 周 琪. 水污染控制工程(下册). 北京:高等教育出版社, 2007:205-350.

[13] Nurnberg GK. Trophic state of clear and colored, soft-and hard-water lakes with special consideration of nutrients, anoxia, phytoplankton and fish. Lakes and Reservoir Management, 1996, 12(4) : 432-447.

[14] 刘聚涛,高俊峰,赵家虎等. 太湖蓝藻水华灾害程度评价方法. 中国环境科学,2010,30(6):829-832.

[15] 缪 灿, 李 哇, 余冠军. 巢湖夏、秋季浮游植物叶绿素 a 及蓝藻水华影响因素分析. 生物学杂志, 2011,28(2): 54-57.

[16] 钟立香. 巢湖水一沉积物系统中氮的赋存变化及其与水华发生的关系研究 [学位论文]. 北京: 中国环境科学研究 院, 2009 .

[17] 孔 明,张 路, 尹洪斌等. 蓝藻暴发对巢湖表层沉积物氮磷及形态分布的影响. 中国环境科学, 2014,34 (5): 1285-1292.

[18] Schöne K, Jähnichen S, Ihle T et al. Arriving in better shape: Benthic Microcystis as inoculum for pelagic growth. Harmful Algae, 2010, 9(5): 494-503.

[19] 邹 清, 周连凤, 吴生桂. 巢湖周年水质的综合评价. 水利渔业, 2007,27(4):57-59.

[20] Gao Y, Cornwell JC, Stoecker DK et al. Effects of cyanobacterial-driven pH increases on sediment nutrient fluxes and coupled nitrification-denitrification in a shallow fresh water estuary. Biogeosciences, 2012, 9(7): 2697-2710.

[21] Zhu Q, Aller RC, Fan Y. Two-dimensional pH distributions and dynamics in bioturbated marine sediments. Geochimica et Cosmochimica Acta, $2006, \mathbf{7 0}(19)$ : 4933-4949.

[22] Hu CW, Hu F, Zhang Z et al. Sediment resuspension in the Lake Taihu, China. Chinese Science Bulletin, $2006, \mathbf{5 1}(6)$ : $731-737$.

[23] Xu H,Paerl HW, Qin BQ et al. Nitrogen and phosphorus inputs control phytoplankton growth in eutrophic Lake Taihu, China. Limnology and Oceanography, 2010, 55(1):420-432.

[24] 李 柯, 关保华, 刘正文. 蓝藻碎屑分解速率及氮磷释放形态的实验分析. 湖泊科学, 2011, 23 (6) :919-925. DOI 10. 18307/2011.0614.

[25] 张彩云, 周北海, 姜 霞等. 蓝藻水华对沉积物水界面氮交换的影响. 环境科学与技术,2014,37(12):38-44.

[26] 王书航,姜 霞,钟立香等. 巢湖沉积物不同形态氮季节性赋存特征. 环境科学, 2010,31(4):946-953.

[27] Kritzberg ES, Cole JJ, Pace ML et al. Autochthonous versus allochthonous carbon sources of bacteria: Results from wholelake super ${ }^{13} \mathrm{C}$ addition experiments. Limnology and Oceanography, 2004, 49(2) : 588-596.

[28] 处逢宇, 霍守亮, 席北斗等. 巢湖近代沉积物及其间隙水中营养物的分布特征. 环境科学学报, 2010, 30 (10): 2088-2096.

[29] 周志华, 刘丛强, 李 军等. 巢湖沉积物 $\delta^{13} \operatorname{Corg}$ 和 $\delta^{15} \mathrm{~N}$ 记录的生态环境演化过程. 环境科学, 2007, 28 (6): $1338-1343$. 